\title{
Investigation of the Relationship between IgG and Telomerase in Simental Cattle
}

\section{in Different Age Groups}

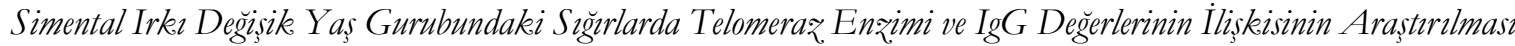

\section{Serkan ÇETİNER ${ }^{1}$, Şima ŞAİNDURAN ${ }^{*}$}

${ }^{1}$ Burdur Mehmet Akif Ersoy University, Faculty of Veterinary Medicine, Department of Internal Medicine, Burdur, Turkey

\begin{abstract}
Preservation of telomere length suggests that it can play an active role in avoiding diseases that can be seen with aging and in avoiding cellular aging. Telomeres shorten slightly with each cell division. Telomerase enzyme is responsible for elongation of telomere sequences. Immunoglobulins can be thought of as the molecular structure of antibodies. IgG making up $75-80 \%$ of antibodies. The aim of this study is to evaluate the levels of $\operatorname{IgG}$ and telomerase enzyme, which have an important place in the immune system with aging. The research material consisted of a total of 46 animals of Simmental breed, 1-day-old 8 calves, 6 -month-old 8calves, 1 -year-old 8 calves, 4-year-old 12 and 6-year-old 10 cattle in various farms. After the blood samples taken from the animals were centrifuged, their serums were removed and telomerase enzyme levels and IgG levels were measured and compared by ELISA method. As a result, in this study, it was observed that telomerase enzyme activity decreases with aging. While IgG levels did not decrease in the first four groups, a positive correlation was found between IgG and telomerase values in 6-yearold animals. In addition, no significant difference was observed in animals in the same age groups.
\end{abstract}

Keywords: Age, Cattle, IgG, Telomerase.

Öz: Telomer uzunluğunun muhafaza edilmesi yaşlanmayla görülebilecek hastalıklardan kaçınmak ve hücresel yaşlanmadan sakınmada etkin bir rol üstlenebileceğini akıllara getirmektedir. Telomerlerin boyları her hücre bölünmesinde bir miktar kısalır. Telomer dizilerinin uzatılmasından telomeraz enzimi sorumludur. Immunglobulinler, antikorların moleküler yapısı olarak düşünülebilir. IgG antikorların \%75-80’nini oluşturur. Bu çalışmanın amacı yaşın ilerlemesi ile immun sistemde önemli yeri olan $\operatorname{IgG}$ ile telomeraz enziminin seviyelerini değerlendirmektir. Araştırma materyalini, çeşitli çiftliklerde bulunan Simental 1rkı, 1 günlük buzağı 8 adet, 6 aylık buzağ1 8 adet, 1 yaşında dana 8 adet, 4 yaşında 12 adet ve 6 yaşında 10 adet sığır toplam olarak 46 hayvan oluşturdu. Hayvanlardan alınan kan örnekleri santrifüj edildikten sonra serumları çıkarılarak ELISA yöntemi ile telomeraz enzim düzeyleri ve IgG düzeyleri ölçülüp karşılaştırıldı. Sonuç olarak bu çalışmada yaşlanmayla birlikte telomeraz enzim aktivitesinin azaldığı gözlenmiştir. İlk dört grupta IgG düzeyi azalmazken 6 yaşındaki hayvanlarda IgG ve telomeraz değerleri arasında pozitif korellasyon ilişkisi saptanmıştır. Ayrıca aynı yaş gruplarında olan hayvanlarda anlamlı fark gözlenmedi.

Anahtar Kelimeler: IgG, Suğır, Telomeraz, Yaş.

${ }^{*}$ Corresponding author : Şima ŞAHINDURAN e-mail : sahinduran@mehmetakif.edu.tr

Geliş tarihi / Received : 10.06.2021 Kabul tarihi / Accepted: 26.08.2021

\section{Introduction}

The immune system protects the organism against foreign substances and tumor cells. Fights virus and bacterial infections. It can be considered as a system consisting of some cells and organs that protect the body against abnormal biological factors. If the immune system loses its resistance and the level of immunity decreases, diseasecausing factors may develop in the body. Suppression of the immune system weakens the body's defense mechanism against pathogenic microorganisms (Wilkie, 1974). Respiratory and 
digestive problems that can be frequently seen in newborn calves may be immunological, genetic, microbiological, physical, psychological and nutritional (Roy, 1980). It has been reported that immunoglobulins are used in cases of passive transfer failure, myelofibrosis, autoimmune thrombocytopenia and hemolytic anemia that may occur in newborns (Kol, 2008). The antigenic, physiochemical and biological properties of immunoglobulins differ. They are structurally diverse. 4 types of immunoglobulins were observed in ruminants as $\operatorname{Ig} \mathrm{A}, \operatorname{Ig} \mathrm{G}, \operatorname{IgM}$ and $\operatorname{IgE}$ (Bergmann-Leitner, 2008). IgG, which is the most abundant immunoglobulin in the blood, constitutes almost $85-90 \%$ of the immunoglobulins found in blood serum and colostum (Klaus et al., 1969). IgG's can bind to two antigens due to their bivalent structure. It can participate in the agglutination reaction with 2 bacteria or form an immune complex (Gershwin, 1990). IgG have an effective role in bacterial agglutination and opsonization, toxin neutralization and virus neutralization (Mehra et al., 2006).

Telomerase activity is an important determinant of telomere length in mammalian cells, in which lack of telomerase activity could exacerbate cell senescence, especially in highly proliferative tissues (Richard son et al., 2014). Telomerase activity has been shown to be specifically expressed in immortal cells, cancer and germ cells where it compensates for telomere shortening during DNA replication and thus stabilizes telomere length (Harley, 1997). It affects not only the telomere, but also the immune and cell functions (Effros, 2011). In some studies, it has been observed that it has a short and long-term effect on the immune system, and it has been reported that telomere shortening causes a decrease in defense against infections (Miller, 2000). Telomere activity and telomere length are effective in the pathobiology of diseases that can be seen in humans (Blasco, 2005). Oxidative stress that increases in diseases negatively affects telomere sizes. In studies on fibroblasts, it has been reported that oxidative stress affects telomere lengths to a large extent. In this study on fibroblasts, it was reported that oxidative stress factor inhibits telomerase enzyme activity in telomeres and causes more damage compared to non-telomeric chromosomal DNA (Von Zglinicki, 2000). The aim of this study is to investigation of the relationship between $\operatorname{IgG}$ and telomerase immunglobulin in Simental Cattle in different age groups.

\section{Materials and Methods}

This study was conducted within the scope of the Board decision of Burdur Mehmet Akif Ersoy University Rectorate Animal Experiments Local Ethics Committee dated March 13, 2019 and numbered 503.

The research material was composed of cattle in farms in Burdur province. The animals to be used in this research study are in different age groups and blood samples were collected on the condition that they are only Simental race. Blood samples were collected from a total of 46 animals. Group 1: 8 calves ( 4 females, 4 males) of 1 day old, Group 2: 8 calves ( 4 females, 4 males) of 6 months, Group 3: 8 calves ( 4 females, 4 males) 1 year old (Heifer), Group 4: 4 years old 12 (6 female, 6 male) cattle, Group 5: 6 year old 10 (5 female, 5 male) Simental breed cattle were used. Those who are 1 day old took colostrum up to $10 \%$ of their live weight. No disease symptoms were observed during the blood collection process, and no problems were found in eating and drinking and physiological functions. Vaccines were made within the routine vaccination program of the Ministry of Agriculture and Forestry (Brucella, alum, LSD). Venous blood samples from all cattle were taken from the vena jugularis into negative pressure tubes with the help of a 21 gauge needle Vacutainer ${ }^{\circledR}$ holder. Siliconebased plastic tubes $(9 \mathrm{ml})$ with clot activator were used for serum samples. The collected blood samples were ensured to coagulate, and their serums were removed in a centrifuge device at $4000 \mathrm{rpm} / 5 \mathrm{~min}$. The extracted serum samples were evenly transferred to Eppendorf tubes (1.5 
$\mathrm{ml}$ ) using a micropipette. The tubes recorded by writing sample numbers on them were stored at $20^{\circ} \mathrm{C}$ until they were processed. A total of 46 blood serum from all cattle was measured for telomerase enzyme and IgG by ELISA test. The Bio-X Diagnostics S.A ELISA, Belgium 'test was used for immunoglobulin. For the telomerase enzyme 'Mybiosource For the quantitative detection of Bovine Telomerase catalog Number: MBS281594) was used.

\section{Statistical Analysis}

Findings were evaluated using IBM SPSS 22.0 for Windows package program. Shapiro-Wilk test was used to determine the compatibility of the data for normal distribution. Multi-group comparisons were determined by the Kruskal-Wallis test, since the data were not distributed normally. Spearman Correlation coefficient was used to analyze the relationship between variables.

\section{Results}

Blood samples were collected from a total of 46 animals in the study. According to the results, although the value of telomerase enzyme gradually decreased, statistically no significant difference was observed in animals between 1 day and 6 months of age and between 1 year and 4 years old animals. However, a significant decrease in the level of telomerase enzyme was detected in animals aged 6 years. According to our findings, the level of telomerase enzyme decreased with the advancement of age. When looking at the level of IgG in 1-day-old animals, it was at the lowest level and increased to 4 years of age, while a decrease was observed after 6 years (Table 1). In the study, no significant difference was found in animals of the same age group. There was no change according to gender.

\section{Discussion}

According to scientists, with increasing age, the body's vulnerability to infection gradually increases (Tarry-Adkins et al., 2019). Age-related decline in immunity is characterized by stem cell depletion, telomere shortening and impaired cellto-cell communication, resulting in an increased patient risk of disease. Recent data have shown that chronic inflammation has a strong effect on immune aging and is closely related to telomere length (Jose et al., 2017). Aging is associated with the increasing prevalence of multiple comorbidities, including infectious and malignant diseases. Many of these disorders are thought to be caused by a decline in immunity due to aging. The immune system consists of a large number of different immunocompetent cells with specific functions that regroup into the adaptive or innate arms of the immune system. In recent years, increasing efforts to characterize the immune system of elderly people have revealed that most immunocompetent cell compartments have qualitative and quantitative impairments (Giraudeau et al., 2019). Studies examining telomere length and telomerase activity focus on the potential interactions between inflammation and telomere biology in immunological aging. Telomere shortening during cell division is a critical process in the progression to aging, and telomerase may play an important role in immunological aging (Jose et al., 2017). IgG, which is the most abundant immunoglobulin in blood, constitutes approximately $85-90 \%$ of immunoglobulins in blood serum. Immunolubin Gs are molecules produced by the immune systems of multicellular animal organisms to combat organic structures that are not of their own. They have a glycoprotein structure. They can be detected in all body fluids (Tizard, 2004). In this study, the values of $\operatorname{IgG}$ and telomerase enzymes in cattle of different age groups were investigated. A significant difference was found between the $\operatorname{IgG}$ values of one-day-old newborn calves and the values of 6 months old, 1 year old, 4 years old and 6 years old cattle and the values were observed to increase gradually. However, while $\operatorname{IgG}$ values increased from 1 day to 4 years old, a decrease was detected in animals aged 6 years. According to our findings, as the age increases from the first day of birth to the age of 4 , the level of IgG increases and the immune system becomes stronger. However, with the effect of increasing age and aging, the level of $\operatorname{IgG}$ and consequently weakening of the immune system were observed after 4 years of age, and a significant difference was found between the groups $(\mathrm{p}<0.05)$. Because the cattle population over 6 years old is very low in the livestock sector 
and cattle are slaughtered after a certain age, older animals could not be included. According to Tarry-Adkins et al. (2019), the rate of immunodeficiency and infection increases significantly with age, and the vulnerability of the body due to age gradually increases. Our findings are in line with the findings of the aforementioned researchers. The findings showing that the infection accelerates telomere erosion in immune cells has been supported by experimental studies on laboratory animals (Giraudeau et al., 2019). Jose et al. (2017) revealed in their study that it is characterized by age-related decline in immunity, stem cell depletion, telomere shortening, and cellcell communication impairment, which leads to an increased risk of disease. With increasing age, as a result of the weakening of the body's defense mechanism and immune system, infections increase and telomere length is negatively affected by the effect of oxidative stress. Telomeres are among the first to be affected by acute oxidative stress, and therefore, it has been reported that there is no repair mechanism for single chain fractures, and to a lesser extent, chronic oxidative stress accelerates the shortening of telomere lengths (Von Zglinicki et al., 2000). Leukocyte's telomere length (LTL) is a biomarker of inflammation and oxidative stress that predicts the risk of chronic diseases with increasing age (Flannagan et al., 2020). Brümmendorf et al. Conducted a study in 2002 in cats aged 2-10 years. In this study, telomere lengths in lymphocytes and granulocytes were measured. According to the study data, telomere lengths gradually decreased with increasing age. In our study, the value of the telomerase enzyme gradually decreased with the increasing age. The highest value was observed on the first day of delivery and the lowest value was observed at age $6(\mathrm{p}<0.05)$. According to our results, no significant difference was found in the decrease of telomerase enzyme between 1 day and 6 months, but a statistically significant difference was found after 1 year of age.

Table 1. Serum telomerase and IgG levels in different age groups in Simental cattle.

\begin{tabular}{|c|c|c|c|c|c|c|}
\hline & $\begin{array}{l}\text { Group } \\
1(n=8) \\
\bar{x} \pm s s\end{array}$ & $\begin{array}{c}\text { Group } \\
2(n=8) \\
\bar{x} \pm s s\end{array}$ & $\begin{array}{c}\text { Group } \\
3(n=8) \\
\bar{x} \pm s s\end{array}$ & $\begin{array}{c}\text { Group } \\
4(n=12) \\
\bar{x} \pm s s\end{array}$ & $\begin{array}{c}\text { Group } \\
5(n=10) \\
\bar{x} \pm s s\end{array}$ & $\boldsymbol{P}$ \\
\hline $\begin{array}{c}\text { Telomer } \\
\text { ase } \\
(\mathrm{ng} / \mathrm{ml})\end{array}$ & $0,33 \pm 0,10^{a}$ & $0,31 \pm 0,68^{a}$ & $0,26 \pm 0,30^{\mathrm{b}}$ & $0,22 \pm 0,39^{b}$ & $0,04 \pm 0,03^{c}$ & $<0,001$ \\
\hline $\begin{array}{c}\text { IgG } \\
(\mathrm{ngr} / \mathrm{mL})\end{array}$ & $20,21 \pm 17,40^{a}$ & $33,18 \pm 11,12^{\mathrm{ab}}$ & $46,32 \pm 11,70^{\mathrm{b}}$ & $49,18 \pm 17,32^{\mathrm{b}}$ & $34,10 \pm 13,12^{\mathrm{ab}}$ & $<0,001$ \\
\hline
\end{tabular}

There is a statistical difference between columns containing different letters $(\mathrm{p}<0.05)$.

In the results of working; It was observed that the advancement of age and the activity of the telomerase enzyme also affected the decrease in the activity of $\operatorname{Ig} G$, which is an important element of the immune system. Although the levels of telomerase enzyme decreased over time, IgG levels did not decrease in the first four groups, while a positive correlation was found between $\mathrm{IgG}$ and telomerase values in 6-year-old animals with advancing age. As can be seen from different studies, it supports the thesis we put forward. In this study, the changes in telomerase enzyme and immunoglobulin $\mathrm{G}$ levels with the advancement of age were investigated for the first time in the field of veterinary medicine. In this way, the effect of age on the body's immune system will be investigated, and it will be possible to take precautions for diseases or problems that may arise at an advanced age.

\section{Acknowledgments}

This study was supported by Mehmet Akif Ersoy University Scientific Research Projects Commission (Project No: 0582-YL-19).

\section{References}

To cite this article: CETINER S, S AHINDURAN S. (2021). Investigation of the Relationship between IgG and Telomerase in Simental Cattle in Different Age Groups.. MAKU J. Health Sci. Inst., 9(2), 23-27. 
Bergmann-Leitner, E.S., Mease, R.M., Duncan, E.H., Khan, F., Waitumbi, J., Angov, E., 2008. Evaluation of immunoglobulin purification methods and their impact on quality and yield of antigen specific antibodies. Malaria Journal 7, 129-138.

Blasco, M.A., 2005. Telomeres and Human Disease: Aging, Cancer and Beyond. Nature Reviews: Genetics 6, 611-22.

Brümmendorf, T.H., Mak, J., Sabo, K.M., Baerlocher, G.M., Dietz, K., Abkowitz, J.L., 2002. Lansdorp PM. Longitudinal studies of telomere length in feline blood cells: implications for hematopoietic stem cell turnover in vivo. Experimental Hematology 30, 1147-1152.

Chiu, C.P., Harley, C.B., 1997. Replicative senescence and cell immortality: The role of telomeres and telomerase. Proceeding of the Society for Experimental Biology and Medicine 214, 99-106.

Effros, R.B., 2011. Telomere/telomerase dynamics within the human immune system: Effect of chronic infection and stress. Experimental Gerontology 46(23), 135-140.

Flannagan, K.S., Bowman, A.A., Mora-Plazas, M., Marin, C., Rentschler, K.M., Rozek, L.S., Villamor, E., 2020. Micronutrient status and leukocyte telomere length in school-age Colombian children. European Journal of Nutrition 59, 3, 1055- 1065.

Gershwin, L.J., 1990. The physiochemical and biological basis of immunity. In: E.L. Biberstein and Y. Chung Zee (Ed.), Review of Veterinary Microbiology. Boston, Oxford, London, Edinburgh, Melbourne: Blackwell Scientific Publications 9-39.

Giraudeau, M., Heidinger, B., Bonneaud, C., Sepp, T., 2019. Telomere shortening as a mechanism of longterm cost of infectious diseases in natural animal populations. Biology Letters 15, 5 .

Harley, C.B., 1997. Human ageing and telomeres. In: Telomeres and Telomerase, Ed.: D.J. Chadwick, G. Cardew, West Sussex: John Wiley and Sons, 129-147.

Jose, S.S., Bendickova, K., Kepak, T., Krenova, Z., Fric, J., 2017. Chronic inflammation in immune Aging:
Role of pattern recognition receptor crosstalk with the telomere complex?. Frontiers in Immunology 8.

Klaus, G.G., Bennet, B.A., Jones. E.W., 1969. A quantitative study of the transfer of colostral immunoglobulins to the newborn calf. Immunology 16, 293-299.

Kol, A., 2008. Human intravenous immunoglobulin (IVIG) therapy in veterinary medicine-A review. Israel Journal of Veterinary Medicine 63 (1), 23-27.

Mehra, R., Marnıla, P., Korhonen, H., 2006. Milk immunoglobulins for health promotion. International Dairy Journal 16, 1262-1271.

Miller, R.A., 2000. Telomere diminution as a cause of immune failure in old age: an unfashionable demurral. Biochem Soc Trans 28(2), 241-5.

Richard son, R.B., Allan, D.S., Le, Y. 2014. Greater organ involution in highly proliferative tissues associated with the early onset and acceleration of ageing in humans. Experimental Gerontology 55, 8091.

Roy, J.H.B., 1980. Factors affecting susceptibility of calves to disease. Journal of Dairy Science 63, 650-664.

Tarry-Adkins, J.L., Aiken, C.E., Ashmore, T.J., Ozanne, S.E., Spiroski, A.M., Sutherland, M.J., Camm, E.J., Giussani, D.A., Rolfo, A., 2019. A suboptimal maternal diet combined with accelerated postnatal growth results in an altered aging profile in the thymus of male rats. Faseb Journal 33, 1, 239-253.

Tizard, I.R., 2004. Veterinary Immunology: An Introduction. (7th ed.). Philadelphia, Pennsylvania: Saunderes.

Von Zglinicki, T., Pilger, R., Sitte, N., 2000. Accumulation of single-strand breaks is the major cause of telomere shortening in human fibroblasts. Free Radical Biology and Medicine 28, 64-74.

Wilkie, B.N., 1974. Review of Bovine Immunology for the Veterinary Practitioner. The Canadian Veterinary Journal 15(9), 243-248. 